\title{
Institutionalizing Japan's Relief System for Repatriates: Koreans and Japanese at Hakata Port in 1945*
}

Youngho Choi*

\section{Introduction}

During World War II, the Japanese government promoted the migration of Koreans to the Japanese colonies, as well as to the main Japanese islands. By the end of the war, around two million Korean people lived in all the provinces in mainland Japan, and approximately more than half of them were coerced into forced labor in private companies and in the Japanese armed forces. On the other hand, the Imperial government had encouraged Japanese individuals and families to migrate to Korea, Manchuria, China and other countries in compliance with the expansion of colonies and battle areas. Consequently, at the time of the war's conclusion, around two million Japanese people were scattered in Northeast Asia,

* This study was supported by a 2014 research grant from Youngsan University in the Republic of Korea. I started to investigate the relief system for repatriates at Hakata port during my stay in Fukuoka city from April to June 2014 as a visiting professor at the Research Center for Korean Studies at Kyūshū University. I submitted a report titled "Relief System for Repatriates in Hakata Port soon after the War End" to the Japan-Korea Cultural Foundation with their generous funding in the same year. I wrote this article after making revisions to the original paper using newly discovered resources and with the advice of my colleagues.

** Professor, Department of Japanese Business, Youngsan University, Pusan, South Korea. 
away from their home country. The arrival of peace necessitated repatriating those Japanese abroad who were faced with worsening security conditions as well as the Koreans in Japan who desired to return to their home. ${ }^{1}$

Critical questions have constantly appeared in the outcomes of my scholarly research on the liberation period in Korea. What was the liberation of Korean people like then? How did the returning home of the Korean people differ from the repatriation of the Japanese? Why did antiJapanese sentiment among Koreans increase so soon after liberation? I think all these questions come from the consistent ethnic discrimination of Japanese authorities at that time. Thus, this is why I attempt to uncover the reality of discrimination by Japanese officers against Korean returnees in the institutionalizing process of the relief system in Japan soon after the end of the war when most Japanese war victims in the northern part of Korea and China became stranded.

\section{Methods and Resources}

I employ a historical approach which looks closely into resources and documents in the search for historical evidence. I try to verify the relief

1 Tessa Morris-Suzuki, a researcher on the immigration of Koreans in postwar Japan who described that there were around 660,000 Korean civilians, underestimated the number of female recruits who had been conscripted to work in Japan, and over 360,000 people drafted as servicemen or auxiliaries to the armed forces. Jun Uchida, a researcher on the Japanese people in colonial Korea, revealed that around 700,000 Japanese civilians and around 300,000 army personnel had been in Korea. A researcher on Japanese repatriation estimated that over 7,000,000 Japanese people including 3,500,000 military personnel had left the mainland. Tessa Morris-Suzuki, Borderline Japan: Foreigners and Frontier Controls in the Postwar Era (New York: Cambridge University Press, 2010), 39; Jun Uchida, Brokers of Empire: Japanese Settler Colonialism in Korea 1876-1945 (Cambridge: Harvard University Asia Center, 2011), 3; Wakatsuki Yasuo, Sengo Hikiage no Kiroku (Records of the Postwar Repatriation) (Tokyo: Jijitsūsinsha, 1991), 46-8. 
activities for repatriates at Hakata port which was where the largest number of people boarded and disembarked ships to and from Korea. I mainly investigate what the Japanese authorities of the port did for Korean repatriates with respect to transportation, medical care, sheltering, rations, and other accommodations. It is said in general that the Japanese government neglected the needs of former colonial subjects, both Koreans and Chinese, who were returning to their homelands from Japan through seaports in that period. Consequently, the central authority did not earmark a working budget for repatriation relief of non-Japanese residing in Japan and local authorities did not even conduct head-counts of non-Japanese, which is in sharp contrast with the way they handled the repatriation of ethnic Japanese. ${ }^{2}$

Kyokushi (hereafter, The History of the Bureau) published by the Hakata Relief Bureau for Repatriates shows that 273,597 Japanese civilian repatriates arrived at Hakata port between September 1945 to March 1946 including 242,568 persons from the Korean peninsula, 17,174 people from central China, 13,601 people from northern China and 254 people from the Philippines. And according to the report, 425,713 Korean and 9,724 Chinese departed from the port during the same period, but no monthly details of non-Japanese repatriates were reported. The majority of Japanese residents on the Korean peninsula returned to Japan through Hakata port and vice versa in the postwar period. As the number of repatriates peaked in mid-1946, when many Japanese civilians entered Japan leaving Manchuria, the port became synonymous with the phrase 'port of

2 The Japanese government reported 694,155 Japanese repatriates returned to Japan from September to November 1945. The authorities designated several ports to be used as entry points into Japan. 273,687 people returned to their country through Hakata port, 217,066 through Senzaki, 100,674 through Sasebo, 62,106 through Uraga, 12,788 through Maizuru, 19,372 through Kagoshima, 6,303 through Ujina and 2,159 through Ōtake. Hikiage Engochou (The Relief Agency for Repatriates), Hikiage Engo no Kiroku (Records of Relief Activities for Repatriates) (Tokyo: Hikiage Engochou, 1950), separate index. 
repatriation. ${ }^{3}$

The History of the Bureau is the most substantive material for this research as well as its supplement, especially 'Table Talks Preceding the Opening of the Bureau,' which is the record of round table discussions held in a restaurant near Hakata port on the afternoon of April $7^{\text {th }}, 1947 .^{4}$ Vivid reminiscences of the persons involved in the relief activities gives us much valuable information about the overall repatriation procedure at the beginning stage. Another resource, Jimuhikitsugisho (hereafter, Transfer of Business) issued by the Fukuoka Prefectural Government when the prefectural governor changed on October $27^{\text {th }}, 1945$, should not be overlooked because it is an official document including historical evidence of the institutionalization of relief activities in Fukuoka. At that time, most of the gubernatorial governors resigned their seats of political responsibility with Japan's defeat in World War II . Contents of the report had been prepared by all subsidiary departments of the local government for submission and reported to their new governor. Transfer of Business also reveals the deployment process of the occupational forces in Fukuo$\mathrm{ka}^{5}$

Among previous research on the process of the relief system for repatriates at Hakata port, two researchers should be mentioned for their out-

3 Fukuoka Shiyakusho (Fukuoka City Hall), Fukuoka Shishi Dai 5 kan: Shōwahen Gohen 1 (History of Fukuoka City Vol. 5: Second Part of Showa Period 1) (Fukuoka: Fukuoka Shiyakusho, 1970), passim; Lori Watt, When Empire Comes Home: Repatriation and Reintegration in Postwar Japan (Cambridge: Harvard University Asia Center, 2009), 95.

4 There were 16 participants in the meeting titled 'Table Talks about before Opening the Bureau' who had the important roles in the relief activities before the Repatriation Bureau opened. In addition, the correspondents of five newspaper offices in Fukuoka also attended the meeting as observers. Hakata Hikiage Engo Kyoku (Hakata Relief Bureau for Repatriates), Kyokushi (History of the Bureau) (Fukuoka: Kuromizu Publishing, 1947), 174-205.

5 Fukuokaken (Fukuoka Prefecture), Jimuhikitsugisho (Transfer of Business) (Fukuoka: Fukuoka Prefectural Government, 1945), 15. 
standing investigative efforts. Kaoru Izumi, who made an analysis of the History of the Bureau in his publication of 1993, is the first researcher to explore this matter. He uncovered the relief activities for Korean repatriates by referring to news articles from a newspaper, Nishi-Nippon Shimbun, as well as official documents. Kumi Suzuki conducted a study on the movements of Koreans and of the relief system for Koreans at the port in her article of 2009, referring to various documents including Seiki Shimbun. She submitted her doctoral dissertation to Hitotsubashi University in 2014 in which she portrayed the official policies regarding Korean residents in Tōkyō, Ōsaka, Shimonoseki and Fukuoka. Compared to previous research, this article focuses specifically on the embryonic stages of the relief system and explores the activities revealed through various resources.

In order to understand the relief environment for repatriates at Hakata in greater detail, we need a critical analysis of the materials such as the image archives taken by U.S. Forces in October 1945. There are several books published in Japan after the 1980s containing images of the port. ${ }^{6}$ The Meeting Considering Repatriation Port Hakata (MCRPH) displays photo collections from Japanese repatriates on the Internet and it has exhibited them in the pavilion in Fukuoka city since 2011. Now we can view part of the films related to the port, taken by soldiers of the $32^{\text {nd }} \mathrm{Di}$ vision of the U.S. Army, in the Film Archives Division of Fukuoka City Library. Also, RKB Mainichi TV, now located in Fukuoka city, televised the first documentary program on repatriates at Hakata port in 1978, and a second documentary in 2012.

The reminiscences of both repatriates and relief activists can also be important resources to understand the circumstances of Korean repatriates.

6 Kimura Hideaki, Shinchūgun ga Utsusita Fukuoka Sengo Shasinshū (Photograph Collection of Post War Fukuoka Taken by Occupation Forces) (Fukuoka: Seitokyō Publishing, 1983), 1-128; Kimura Hideaki, Beigun ga Utsusita Shūsen Chokugo no Fukuokaken (Post War Fukuoka Prefecture Photographed by American Army) (Fukuoka: Meeting Considering Repatriation Port Hakata, 1999), 1-96. 
In 1995, MCRPH published a collection of the reminiscences of repatriates who came into the port and the people who worked in the relief organizations in postwar Fukuoka in commemoration 50 years after the war. ${ }^{7}$ Among the memoirs to which around 70 persons contributed to this collection, I think two are especially noteworthy. The first one is from Seigo Shimizu, an official witness in the relief organization at the port, who wrote about the gulf between the war victims and the common repatriates. And the second one is from Kwangryeol Kim, a Korean historian who lived in Fukuoka, and who coined the memorable phrase, 'the Korean repatriate had never been treated as human' referring to ethnic discrimination by the Japanese government.

\section{Korean and Japanese Repatriates Rushing to the Ports}

The sudden downfall of the Japanese empire, accompanied by the liberation of Korea, triggered massive migration in both countries. Many Koreans lost their lives on small unregulated ferries while crossing the Strait of Korea soon after the end of the war. ${ }^{8}$ Above all, Fukuoka and Shimonoseki were so crowded with Korean returnees that a chaotic situation ensued. Approximately four thousand Korean ex-soldiers discharged

7 引揚港・博多を考える集い (Meeting Considering Repatriation Port Hakata), Sengo 50 nen Hikiage wo Omou: Asia no Yūkō to Heiwa wo Motomete (50 years After the War, Considering of the Repatriation: Pursuing the Asian Friendship and Peace) (Fukuoka: Meeting Considering Repatriation Port Hakata, 1995).

8 Edward W. Wagner, The Korean Minority in Japan: 1904-1950 (New York: Institute of Pacific Relations, 1951), 49; Mary Virginia Darmstadter, "The Korean Minority in Post-War Japan: Repatriation of Korean Residents in Japan" (MA Diss., The American University, 1963), 13; Changsoo Lee et al., Koreans in Japan: Ethnic Conflict and Accommodation (Berkeley \& Los Angeles: University of California Press, 1981), 58; Park Kyeong Sik, Kaihōgo Zainichi Chōsenjin Undōshi (History of the Movements of Koreans in Japan after Liberation) (Tokyo: Sanichishobō, 1989), 44. 
from military service were waiting for ships at Hakata port by August $24^{\text {th }}$ as well as around ten thousand Korean people including ex-soldiers had flocked to Shimonoseki station by August $29^{\text {th }} .9$

Most of the Japanese colonizers and their families in Korea also rushed to the seashore boarding boats to Japan from ports such as Pusan in order to return to their home country as soon as possible. Evacuation procedures for Japanese civilians and military personnel residing in the northern part of the Korean peninsula and Manchuria had already begun immediately after the Soviet Union's invasion on August $9^{\text {th }}$, 1945. At the end of the war, a substantial number of Japanese evacuees had already arrived in Pusan to return to their home country by available passenger boats. In the early stage of repatriation, the Japanese mainly depended on sailing boats with a motor (kihansen), or motor-powered boats. ${ }^{10}$ Although large passenger ferry services between Korea and Japan resumed in September, individual returnees preferred to take small boats because they could carry more pieces of personal luggage, and they could depart as soon as possible and whenever they wanted. Minoru Yamamoto, as General Director of the Pusan Pier, recalled that many families of high ranking officers from Japanese military units and the Government General of Chosŏn (GGC) snuck out of Korea soon after the war ended, even though Pusan remained serene as there was no remarkable ethnic confrontation at that time. ${ }^{11}$

Yoshitake, whose full name is unclear, was an officer of Fukuoka mentioned in the 'Table Talks Preceding the Opening of the Bureau' who reported that he had witnessed many Japanese people on kihansen boats reaching Hakata port soon after the end of the war. He recounted that they

9 Imaizumi Yūmiko et al., Nihon Teikoku Hōkaiki 'Hikiage' no Hikaku Kenkyū (Comparative Research on the Repatriation in the Time of Collapse of Japanese Empire) (Tokyo: Nihon Keizai Hyōronsha, 2016), 46.

10 Morita Yoshio, Chōsen Shūsen no Kiroku (Records of the War's End in Korea) (Tokyo: Gennandō, 1964), 121-9.

11 Senkōkai, Chōsen Kōtsū Kaikoroku (Memoirs of Korean Transportation: Records on War's End) (Tokyo: Senkōkai, 1979), 251. 
sailed on 'illegal ships' to land any place at high risk. According to him, various kinds of ships departed from Korea carrying Japanese returnees and often arrived at the shores of the towns which were far from the port. He added that a great many small ships rushed to the area between NishiKōen and the port, and that the number of returnees arriving in this way far exceeded the number of those arriving by the way of official ships through October 1945.

The Japanese government suffered from a shortage of vessels at the time and due to the danger of sea-mines remaining in coastal regions it couldn't take the necessary action for the transportation of civilian returnees. According to the U.S. Strategic Bombing Survey, Japan was able to operate only 158 ships of more than 1000 tons by the end of the war because 196 ships had been damaged by air raids in the last phase of the war. Among the super-sized ships of more than 10,000 tons, only four ships remained intact and available for use. ${ }^{12}$ The Japanese Transportation Authority stopped the cross-strait transport services between Korea and Japan two months prior to the war's end because the U.S. Forces commenced the laying of sea-mines in the sea areas and bombing near Japan's islands. Also, most of the ships were heavily damaged from large-scale air raids by the U.S. air forces in July 1945 . When the war ended, the hidden underwater sea-mines along the Japanese coastal areas posed a significant threat to the large ships. ${ }^{13}$ Even though sea-mine clearing operations were initiated in early October, a large number of undiscovered mines still remained off Hakata port in the autumn of 1945. Consequently, both Korean and Japanese migrants were exposed to the risk of detonation. ${ }^{14}$ To make matters worse, harsh weather caused innumerable deaths of the

12 The United States Strategic Bombing Survey. The War against Japanese Transportation 1941-1945 (Washington D.C.: USSBS Transportation Division, 1947), 96-8.

13 Choi Young Ho, Pugwan Yŏllaksŏn'gwa Pusan (Pusan-Shimonoseki Crosschannel Liner and Pusan) (Seoul: Nonhyung Publishing, 2007), 117.

14 航路啓開史編纂会 (Compiling Committee of History of Clearing Sea Route), Nihon no Sōkai: Kōrokaikai 50nen no Ayumi (Japan's Clearing Sea: 50 Years of Clearing Sea Route) (Tokyo: Book Publishing, 1992), 49-50. 
Koreans and the Japanese, who took the dangerous journey on small boats. $^{15}$

While Japanese leadership accepted the Potsdam Proclamation, the central government in Tokyo relatively disregarded the significance of repatriation for Japanese residents abroad. The government decided to declare 'unconditional surrender' on August $14^{\text {th }}$ and sent telegrams to its diplomatic missions abroad concerning their post-war jobs to pay special attention to avoid conflict with other ethnic communities. ${ }^{16}$ The Ministry of Home Affairs organized a new Bureau of General Plans and a Bureau of Management as the subordinate agencies in charge of new tasks. On August $21^{\text {st }}$, the Japanese government began to plan how to relieve and how to carry conscripted soldiers home. The Ministry decided the followings: (1) to demobilize Koreans, (2) to transfer the business of the Army Hospital and the Navy Hospital to the Military Security Hospital, (3) to place the business of harbor inspection and military medical supply under the charge of the Ministry of Welfare, which did not take Korean laborers into consideration. On August $24^{\text {th }}$, the government decided to establish the Interim Demobilization Policy Committee, whose chairman was ViceMinister of the Ministry of Welfare, for reemployment for those discharged from military service and for Japanese returnees from countries abroad. On August $30^{\text {th }}$, the Vice-Ministers' meeting for the Japanese government decided to adopt the Principle of Emergency Relief for Japa-

15 Fukugawa Munetoshi, Chinkon no umi: Kieta Hibaku Chōsenjin Chōyōkō 246 Mei (Strait of the Requiem) (Tokyo: Gendaishi Publishing, 1974), 156-7; Kim Chan Jeong, Ukishima maru Pusankō e Mukawazu (Ukishima-maru didn't head Busan Port) (Tokyo: Kōdansha, 1984), 281; 浮島丸事件下北からの証言発刊をすすめる会 (Promotion Meeting for Publishing Witnesses of Ukishima Incident from Shimokita), Aigō no Umi: Ukishima maru Jiken Shimikita karano Shōgen (The Sea of Ah!: Witnesses of Ukishima Incident from Shimokita) (Mutsu City: Shimokita Local Culture Institute, 1992), passim.

16 Katō Kiyofumi, Kaigai Hikiage Kankei Shiryō Shūsei, Kokugaihen dai 17 kan (Repatriation Resources Collection, Overseas Version, Vol. 17) (Tokyo: Yumanishobō, 2002). 
nese Repatriates, which charged local governments with relief activities for the repatriates, such as housing, nourishment, medical service, rail transportation, money exchange and reemployment services. ${ }^{17}$ For the effective realization of these goals, the government decided to request the assistance and collaboration of the Tokyo liaison offices of the Karafuto Agency, the Government General of Taiwan and Chosǒn. ${ }^{18}$

\section{Emergency Transportation of Government General of Chosŏn (GGC)}

Japanese people in Korea couldn't help but feel at risk when the Soviet Union entered the war against Japan and the Korean people welcomed the Soviet Union as a liberation army regardless of whether or not they were communist. ${ }^{19}$ Then the GGC took the initiative for the transportation of Japanese living in Korea sooner than the Japanese government did. It was found that the GGC sent several telegraphs to Tokyo from the day of Ja-

17 Masuda Hiroshi, Dainippon Teikoku no Hōkai to Hikiage Hukuin (Breakdown of the Japan's Great Empire and Japanese Repatriation) (Tokyo: Keiō University Press, 2012), 19.

18 The Tokyo Liaison Office of GGC was established in 1936 to provide lodgings and offices for GGC bureaucrats while they were in Tokyo on business. Fortunately, the office remained intact at the time of the end of war, and it functioned as an assembly place of the repatriated GGC officers. The Office, whose name was changed to Arranging Office of Remained Korea Office under the SCAP supervision on January 1946, had been utilized for reemployment of Japanese repatriates, paying salary to GGC officers and protecting the property of civil repatriates from Korea until it was requisitioned by SCAP on August 1947. 朝鮮関係残務整理事務 所 (Arranging Office of Remained Korean Affair), Jimusho no Enkaku to Jimugaiyō (History of the Office and Outline of its Activities) (Tokyo: AORKA, 1950), 1-7.

19 Fujiwara Tei, Nagareru Hoshi wa Ikiteiru (Flowing Stars are Alive) (Tokyo: Hibiya Publishing, 1949), 9-17; Watkins Yoko Kawashima, So Far from the Bamboo Grove (New York: Beech Tree Books, 1994), 46-9. 
pan's declaration of surrender, expressing dissatisfaction towards the Japanese government for indifference to its civilians abroad, notably in the records about the end of the GGC regime compiled by Mikio Yamana, chief of General Affairs Section of the GGC. For example, Ryūsaku Endō, the Administrative Superintendent of the GGC sent a telegraph to the Vice-Minister of Home Affairs in Tokyo on August $15^{\text {th }}$ to request guidelines on a course of action to be taken in Korea after the execution of the Royal Edict. Predicting that the Allied Forces would enter the Korean peninsula, the GGC repeatedly reported to the Japanese government about its concern over the hostile sentiment rising among the Korean public against Japanese colonizers and the possibility of civil disturbances in Korea. Nobuyuki Abe, the Governor-General also sent a telegram to the Minister of Home Affairs on August $21^{\text {st }}$ in which he said that disarmament of the Japanese Army would make worse the security situation of the Japanese people residing in Korea, and that the government had to demand that Allied Powers guarantee the security of the Japanese people in Korea. ${ }^{20}$

On August $16^{\text {th }}$, 1945, the Transportation Bureau of the GGC decided to concentrate on transporting food, salt, textiles, sundries, soybean paste and other daily necessities for Japanese victims of war. Also, the Bureau prioritized passengers to board trains as follows: (1) soldiers returning to duty, (2) laborers working in munitions or electric factories and their families, (3) refugees, and (4) women and children. In addition, the Bureau announced a set of railway transportation plans, including the operation of extra train services for Japanese returnees and military personnel on the same train, and indicated that they might even be carried by freight trains in the case of a shortage of passenger trains. ${ }^{21}$ On August $22^{\text {nd }}$ the chief of the Bureau flew to Tokyo and made a verbal request to the Deputy

20 Yūhōkyōkai, Kyuchōsen Sōtokufu Kanbō Sōmukachō Yamana Yukio Shuki (Records on Expiration of the Government General Chosŏn, Written by Mikio Yamana, the Chief of General Affair Section) (Tokyo: Yūhōkyōkai, 1956), 10.

21 Morita, Chōsen Shūsen no Kiroku, 121-2. 
Minister of the Ministry of Transportation for the urgent provision of large vessels for evacuation. However, he learned that the Japanese government had only a limited number of large vessels available at that time. $^{22}$

The local administration of the GGC on the Korean peninsula introduced emergency measures for dealing with mass repatriation. For example, an evacuation plan for Japanese people from Incheon port was devised soon after the war, but it was not put into action after all. ${ }^{23}$ However, the Pusan Regional Transportation Office was able to mobilize 27 cargo vessels carrying Japanese to Hakata over the period from August $17^{\text {th }}$ to August $24^{\text {th }}$, when the Allied Powers did not yet control Japan's capability to operate large ships. Tatsunoshin Naitō, an officer of the Fukuoka Branch of Marine Management, then recalled in the 'Table Talks Preceding the Opening of the Board' that cargo vessels carrying many Japanese people from Korea entered the port without giving any prior notice for entry.

Responding to continued requests by the GGC, the Japanese government decided to provide two large passenger vessels for use between Korea and Japan: the Kōan-maru (7,100 tons) for the route between Pusan and Senzaki, and the Tokuju-maru (3,500 tons) for the route between Pusan and Hakata. Then the Japanese government asked for approval from the General Headquarters of the Supreme Commander for the Allied Power (SCAP) in Manila to operate transport vessels, attaching whitecross signs on their stack decks and bows. Around that time, Korean people were rushing en masse to Shimonoseki or Fukuoka to depart from Japan, while Japanese people rushed to Pusan port to flee from Korea. Migrants in both Korea and Japan had to undergo significant hardships,

22 外務省 (Ministry of Foreign Affairs), Shüsenshiroku (Records of War's End) (Tokyo: Shimbum Gekkansha, 1952), 26-8.

23 Otani Masujirō, Jinsen Hikiageshi: Moto Jinsen Zaijüsha Meibo (Repatriation from Inch'ŏn: Register of Japanese Residents in Inch'ŏn) (Fukuoka: Taiki Co. Ltd, 1952), 5-6. 
such as a shortage of ships and a lack of public security. Therefore, the Japanese government requested SCAP to reopen the cross-channel vessel services between Korea and Japan. The Kōan-maru left Senzaki for Pusan on August $20^{\text {th }}$ and returned to its port of origin on the following day. ${ }^{24}$

On the other hand, Japanese authorities gave little consideration to Korean people awaiting ships in the ports in Japan. Koreans began to gather in crowds at Hakata on August $18^{\text {th }}$, with the number reaching around 2,000 people on August $24^{\text {th }}$. On August $22^{\text {nd }}$, one week after the war ended, the Tokuju-maru arrived in Pusan with Korean returnees who had been forcibly drafted to serve as soldiers in the Japanese Army. Two days later, the ship returned back to Hakata with Japanese returnees. Despite the remaining sea-mines, the ship entered the pier passing through a narrow channel between Nokonoshima and Meinohama, where vessels of 2,000 tons or more had not been allowed to pass hitherto. No evidence has ever been found that any Koreans returned to their home land on the very first voyage of the Kōan-maru, and thus she carried only Japanese returnees from Pusan to Senzaki on August $21^{\text {st }}$.

It is said that perhaps Japanese military personnel and their families who had been in the northeastern area of China might have boarded on the Kōan-maru and the Tokuju-maru. Perhaps the bacteriological unit 731 members who had been stationed in Harbin might have boarded the Tokuju-maru on August $24^{\text {th }}{ }^{25}$ The GGC set up Inquiry Offices on August $27^{\text {th }}$ in Seoul, Pusan, and Shimonoseki to provide necessary information and financial assistance to Japanese civilians and government officials suddenly fired from their jobs. Even though the GGC had no Inquiry Office in Hakata, the local government of Fukuoka Prefecture was criticized

24 Telegraphic Messages to SCAP from Japanese Government on August 20, 1945. These are in the 16th Japanese Diplomatic Documents released by the Japanese government, Reel no. K'0003, Miscellany Related to Protection and Repatriation of Overseas Japanese People due to the End of Pacific War: Ready for the Domestic Reception System and Transportation.

25 Choi Young Ho, Ilbonin Sehwahoe: Singminji Chosŏn Ilboninŭi Chŏnhu (Japanese Relief Society, Post-colonial Repatriates) (Seoul: Nonhyung Publishing, 2013), 80. 
for its neglectful treatment of Japanese returnees by an unidentified highranking official of the GGC whose status remained unknown. According to The History of the Bureau, he arrived in Hakata on August $24^{\text {th }}$ on the same vessel with other Japanese repatriates. His rebuke served as an opportunity for the Fukuoka government to begin providing Japanese returnees with emergency rations, inspection measures, train tickets, and more. ${ }^{26}$ After one week of suspension on account of the deployment of occupational forces in Yokohama not yet in Fukuoka, the Tokuju-maru resumed its shuttle service. It left from Susa in the Yamaguchi prefecture for Pusan on September $1^{\text {st }}$ and departed Pusan with Japanese returnees to arrive at Hakata in the morning on the following day. Later on, it provided regular services for migrants between Pusan and Hakata. Another passenger ferry, the Kōan-maru, resumed its service between Pusan and Senzaki on August $31^{\text {st }}$. Military ships from the U.S. Army began to carry military personnel and civilian returnees from mid-September. ${ }^{27}$

The Nishi-Nippon Shimbun headquartered in Fukuoka, reported on September $5^{\text {th }}$ that the Tokuju-maru carrying 2,764 Japanese repatriates, had entered Hakata two days earlier. The newspaper reported on the situation of the liberated Korean society by interviewing Japanese returnees. It also brought news that around 2,500 disarmed Korean soldiers departed from Hakata for Pusan on the same ferry early in the morning on September $4^{\text {th }}$. In addition, it said that there were innumerable Korean people awaiting ships. The Korean people were asked not to rush to the port because the transportation agency had to accommodate prioritized Korean soldiers in the Japanese imperial army due to the lack of vessels.

\section{Emergency Relief Services of Fukuoka Prefecture}

During wartime, transportation in and out of Hakata was under the con-

26 Hakata Hikiage Engo Kyoku, Kyokushi, appendix 6.

27 Hikiage Engochou, Hikiage Engo no Kiroku, 4. 
trol of the Japanese Army and Navy. But their controlling power was weakened seriously by the air raids of the Allied Powers in the last phase of the war. Numerous marine accidents occurred in the port even soon after the war, due to the chaotic situation in which there was no control tower to regulate the entry and exit of ships. Under such chaotic conditions, matters were made worse by the facts that the Fukuoka Prefectural Government had neither an official announcement on the repatriates nor any orders from the Japanese central government. The Welfare (Kōsei) Department of the prefecture set up an observation point on the rooftop of the administration hall to see whether a big ship would come into the port. Whenever a ship entered, they ran to the pier to inspect and welcome returnees with hardtack, meal tickets, and Repatriation Certificates. There is also a record that the officers of the Livelihood (Minsei) Department in the prefecture also assigned cargo boats bound for Korea for emergency transportation of Korean returnees. ${ }^{28}$

The Welfare Department issued Repatriation Certificates upon arrival in Japan to facilitate relief activities. The certificate was a slightly amended form from the Certificate of Affliction, which the Fukuoka government previously issued for relief of war victims during the war. It became a model for Repatriation Certificates for other areas in Japan. The department also provided emergency food tickets and housing to Japanese repatriates in the early stage when organizations for relief had not yet been established. Post-war relief activities for Korean and Japanese repatriates provided by the Fukuoka government are described in detail in Transfer

28 The Welfare Department had to dust medicinal powder such as DDT on returnees' bodies and luggage on the wharf because there was no inspection room in the port. Nonetheless, the sanitary circumstances for Japanese repatriates were much better than those for Koreans who had to embark on the ship without sanitization. Korean repatriates were sanitized intermittently after an inspection facility was established in the Hakata port on September 27, 1945. Izumi Kaoru, "Haisengo no Hakatakō ni okeru Chōsenjin Kikoku ni tsuite: Hakata Hikiage Engokyoku 'Kyokushi' wo Chūshin ni site (Korean Repatriates in Hakata Port after the Defeat: Investigation mainly on the History of the Bureau)," Hōsei Kenkyū 60-1 (1993): 78-9. 
of Business. The Welfare Department established task force teams of relief provision for Japanese repatriates, such as the General Affairs team, the Nourishment team, the Medical team, the Lodging team, and the Transportation team. The General Affairs team set up a field office in the port and a consultation office in the Hakata Railway Station for Japanese repatriates. The Nourishment team provided them with lunch boxes, hardtack, three days of meal tickets and hot tea. The Medical team provided them with emergency treatment in the Care Room of the Chikkō Railway Station Building with the cooperation of the Sanitation Department of the prefectural government, and also transferred those in critical condition for further intensive care to either a municipal hospital or Saiseikai Hospital by ambulance. The Lodging team provided well-to-do Japanese people with inns in the city, partially subsidized by the government. Impoverished people were transported to public facilities, such as the auditorium of the First Girl's School and two other school buildings, 82 Buddhist temples in the city and places like the Tajima Training Center in Munakata Gun. Finally, the Transportation team helped returnees to the Honshū area (around $60 \%$ of all repatriates) to board temporary trains at the Chikkō Station, and helped all the rest leaving for the greater Kyūshū area to board trains at Hakata Station after being carried by trains, trucks, and horses.

In stark contrast, however, the Fukuoka government was inactive in providing relief to Korean repatriates. Above all, before the Inspection Room was established on the wharf, the government never provided any sanitation services to Korean returnees. The relief activities for Korean repatriates were under the jurisdiction of the Livelihood Department in Fukuoka, Yamaguchi, Ōsaka, and Hokkaidō where there was a substantial number of Korean people in Japan. Up to that time, the department had been handling the Kōseikai organization, established in order to check and control the Koreans living in Japan, including forcibly mobilized laborers and ordinary residents during the war under the direction of the Ministry of Welfare. The department belatedly established a field office for Korean repatriates on September $5^{\text {th }}$ in the building of the JRA (Japa- 
nese Racing Association) near the port. The local government then began to direct Korean people to board ships, and to distribute them to Kōseikai buildings in Fukuoka city. As the JRA offered their stables for use, the department designated the stables as collective camps for Korean people. On September $6^{\text {th }}$, Korean repatriates had to begin to spend nights sleeping in piles of straw where it was windy, smelly and extremely filthy. ${ }^{29}$ In records from the Meeting Considering Repatriation at the Hakata Port, Yeongsang Woo, a Korean returnee told how he passed nights in the open air at the port, and that he saw excrement everywhere due to the lack of toilets. Because the department neglected to provide rations, Korean returnees around the port had to prepare whatever they needed from private purchases at dirty and chaotic black markets near their camps.

In comparison with the report issued by the Welfare Department documenting point by point or article by article the relief activities for Japanese repatriates, the Livelihood Department in the Transfer of Business gave a tedious description of the relief activities carried out on behalf of Korean repatriates under the title 'Concerning Measures for Peninsular Repatriates'. (1) The Livelihood Department office tried to protect and provide guidance for 198,000 Korean people, including 50,000 drafted laborers, residing in Fukuoka Prefecture at the time of the end of the war. (2) The office had to take urgent action because refugees began to crowd around the port soon after the war's end. (3) The office sought out appropriate spaces around the port where Korean people could rest, but managed to only requisition ten buildings from the JRA. (4) The office appropriated 170,000 yen as a national fund for maintenance of the buildings. (5) On average over 1,000 Korean people lodged in those buildings. (6) The office tried to provide such relief services as registration, nourishment, medical service, embarkation guidance, physical protection, and clean up. (7) The officers were stationed in a field office along with members of the Kōseikai and the volunteer relief groups.

Regarding the question of whether there was any ethnic discrimination;

29 Fukuoka Shiyakusho, Fukuoka Shishi Dai 5 kan, 417. 
Yoshitake admitted the fact in the table talks. He said that the local government discriminated against the Korean repatriates saying, "We did not provide meals, clothing or hot tea to Koreans at all from August to October." But Teizō Shiroto, ${ }^{30}$ director of the Livelihood Department differed in his opinion insisting that "Japanese returnees are in a bad situation even being robbed in Korea while Koreans in Japan are neither stripped of their clothes nor have their lives threatened." According to The History of the Bureau, Korean repatriates made complaints of having been unfairly treated in Hakata after landing in Korea. In particular, forced laborers who were mobilized by Japanese authorities complained about the ethnic discrimination in the repatriation procedures, and demanded full payment of back wages they had not received in Japan. As the Japanese Army in Korea was disarmed from mid-September, the atmosphere of anti-Japan sentiment began to reach a boiling point in Korea. The document says that Daewoo Kim, Governor of Gyeongsangnam-do in Korea, sent a petition to the Fukuoka government in September threatening, "If Korean returnees are continuously mistreated by the Japanese authorities, the Japanese residents in Korea will also receive the same treatment in response before they leave." 31

For the Japanese in Korea, the Medical Relief Union had been organized in Seoul on October $11^{\text {th }}$ to provide timely medical treatment while the Japanese traveled by train or by ship. And a free clinic for repatriates opened at the Shōfukuji Temple near the port. ${ }^{32}$ However, medical institutions were not established for Korean people awaiting returning ships, so the majority of them could not receive any medical services in Fukuoka.

30 Teizō Shiroto was appointed as the captain of the Military Affairs Department on January 28,1944 and as the captain of the Livelihood Department on September 1, 1945. Fukuokaken, Jimuhikitsugisho, 15.

31 Hakata Hikiage Engo Kyoku, Kyokushi, appendix 30.

32 Kamitsubo Takashi, Mizuko no Uta: Hikiage Koji to Okasareta Onnatachi no Kiroku (Embryonic Lineage: Records of Repatriated Orphans and Raped Wemen) (Tokyo: Gendaishi Publishing, 1979), 21-4. 


\section{Occupation Forces in Fukuoka}

In SCAP's first instructions regarding repatriation on September $25^{\text {th }}$, G-3 ordered the Japanese government to display the flag of a merchant marine ship instead of a navy flag on any naval ship carrying disarmed Japanese soldiers. This instruction was in reply to a report that almost 4,000 disarmed soldiers would be returning to Japan, leaving Pusan on a daily basis from September $27^{\text {th }}$ (SCAPIN-54). On September $27^{\text {th }}$, SCAP gave an order to Japan that the Economic Science Section would impose restrictions on the numbers of soldiers, their property, and the ships transporting repatriates (SCAPIN-67). On September $28^{\text {th }}$, a section of G-3 gave urgent instructions to prepare the facilities and ports for returning and departing repatriates (SCAPIN-70). Those instructions made it clear, albeit belatedly, SCAP had begun to consider matters concerning civilian repatriation during the last ten days of September. Subsequently, G-3 gave orders on October $7^{\text {th }}$ to establish an office in the vicinity of the port through which repatriates would enter (SCAPIN-100), and on October $12^{\text {th }}$ to install an official organization of the central government responsible for repatriation (SCAPIN-125).

The U.S. Army arrived in Fukuoka slightly later than it did in other areas in Japan. On September $3^{\text {rd }}$, an advance unit of U.S. forces arrived at the Kanoya Air Base in Kagoshima, and this was the first presence of the occupation forces in the Kyūshū area. In Fukuoka, military cargo aircraft landed at the Mushiroda Air Base to transport POWs from Fukuoka on September $15^{\text {th }} .^{33}$ An advance troop of the division landed at the Sasebo port on September $21^{\text {st }}$ followed by the main force landing the next day. Around 1,200 soldiers of the division began to be dispatched to various places in the Kyūshū area. The regimental forces entered Fukuoka after

33 アメリカ戦略爆撃調査団聴取書を読む会 (Meeting for Reading Investigation of United States Strategic Bombing Survey), Fukuoka Kūshū to Amerikagun Chōsa (Air Raids of Fukuoka and Investigation of U.S. Army) (Fukuoka: MRIUSSBS, 1998), 20. 
leaving Sasebo city by train and truck from September $30^{\text {th }}$ to October $1^{\text {st }}$. They immediately set up a command post in the Hakata Hotel to secure lodging in Fukuoka. Inns such as Koshintei, Ippotei and Butokuden in the middle of the city were allocated for officers' lodgings, whereas the Kyūshū airplane factory and the Army munitions warehouse located in Kashii, the eastern part of the city, were allocated for privates' lodgings. Additionally, the $32^{\text {nd }}$ Infantry Division of the U.S. Army led by Commodore McBride, entered Fukuoka on October $20^{\text {th }}$. With the command having been handed over by the $28^{\text {th }}$ regiment, the Infantry Division set up the Command Headquarters in the Chiyoda Building, which was located on the western side of the prefectural administration hall. Around 6,000 6,500 occupational forces were working in Fukuoka in the last ten days of October $1945 .^{34}$

\section{Establishment of a Relief System in the Hakata Port}

Immediately after arrival on Fukuoka, the U.S. Navy began to set up the Post Director's Office and exercise its administrative authority over marine transportation lanes. It checked the entries and departures of vessels as well as facilities for safe navigation on the sea lanes around Hakata port. Furthermore, both Koreans and Japanese repatriates were medically disinfected at an Inspection Station established at the port on October 3, 1945. As a result, the institutional discrimination against Korean repatriates involving health care started to decrease at the port area.

In addition, the U.S. forces checked and arranged the camps for Korean repatriates. According to the Director of the Livelihood Department in the local government, the First Lieutenant of the $28^{\text {th }}$ Regiment, Deats, whose full name is unclear, had observed the unsanitary residential conditions of the stables where Koreans stayed during his inspection tour on October $10^{\text {th }}$. Accompanied by the Chief of Home Affairs Section and the Director

34 Fukuokaken, Jimuhikitsugisho, 111-23. 
of the Livelihood Department, he drove by jeep to several places at the port in the midst of a storm in order to look for alternative camps for Korean repatriates. He proposed that waterfront warehouses would be more suitable for Koreans. Shiroto disagreed with him, stating that those warehouses were not designed to accommodate people and that the horse stables would be renovated in the near future. But Deats directed the officers of the Fukuoka government that they should change the shelters for all Korean repatriates from horse stables to new warehouses by October $12^{\text {th }}$. On the moving day, he assembled about 15,000 Korean people and requested their cooperation for further repatriation procedures.

On the following day, the occupational army ordered the Koreans to clean up the warehouses and Deats had his photograph taken during a site inspection. ${ }^{35}$ The Livelihood Department reported on how the prefectural administration had been involved in moving Koreans from stables to warehouses. According to Transfer of Business, (1) it was ordered on October $10^{\text {th }}$ to move Korean repatriates to new warehouses operated by Fukuoka city, (2) the warehouses were equipped with toiletry and kitchen ware, (3) Koreans were moved to new camps on October $12^{\text {th }},(4)$ the total number of the Koreans in the camp awaiting repatriation was over 10,000 due to a lack of ships in mid-October, (5) the fresh entry of Koreans into the camps was prohibited due to a lack of accommodation space from October $15^{\text {th }}$ to $25^{\text {th }}$, (6) After that, the saturation of space for Koreans was gradually resolved, (7) the disposal of garbage, removal of bomb shelters and ditch-digging around the warehouses was arranged, (8) priority assignment to embark to disarmed soldiers and mobilized laborers was implemented, (9) the number of remaining Koreans as well as those who returned was given as part of a daily report to the U.S. Army from October $8^{\text {th }},(10)$ it was calculated that 99,200 Korean people were repatriated between October $8^{\text {th }}$ and $25^{\text {th }}$.

It was reported that a Korean volunteer group named 'Relief Society for Returning Koreans' was working for emergency relief under the assis-

35 Kimura, Shinchūgun ga Utsusita Fukuoka Sengo Shasinshū, 32-40. 
tance of the Livelihood Department. We should recognize that the group was able to control waiting Koreans and maintain order in the camps. Jeongwoo Nam, the chairman of the group, was the head of a junk company and a member of the Fukuoka Kōseikai. He was so popular among Koreans in Fukuoka that he was elected as the first chairman of the Fukuoka Association of the Koreans in Japan, when the association was established in December $1945 .^{36}$

In November, the U.S. Army issued orders to close the black market near the Korean camps, to re-open them outside the wharf, and to keep order in cooperation with the Fukuoka government, the police office, and the Korean volunteer groups. The Army had also strengthened its supervision over the whole port area by opening a new branch office on November 6, 1945. Later, the Fukuoka government established the Interim Office for Repatriates on November 15, 1945, and Shiroto, Director of the Livelihood Department was appointed as head of the new office. Consequently, the Livelihood Department took full responsibility for relief activities for both Korean and Japanese repatriates. It opened a branch office in a waterfront warehouse building that belonged to the Tsuda Industry Company in the port. An integrated relief system had been developed with a reception center, provision for inspections, medical care, rations, accommodations, and domestic transportation for all repatriates regardless of ethnicity.

The occupation forces also integrated supervision over both the Korean and the Japanese people. On November 19, 1945, the forces gave orders to separate those Koreans who wished to stay in Japan from those who wished to return to Korea with barbed wire fence, which was the first border line in Japan designate the place where Korean residents should be and the place returnees should be. Thus, Korean people in Japan started to

36 The Relief Society for Returning Koreans as a non-official organization was dissolved according to the notice of the occupational forces on February 1, 1946 when the numbers of Koreans waiting for a returning ship in the camp were reduced rapidly to under 4,000. Hakata Hikiage Engo Kyoku, Kyokushi, 98. 
be controlled under draconian policies by the occupational authority at that time. As a result, the Korean people who vacillated due to various reasons had to cross the line at the risk of their own safety. In this context, the barbed wire fence in Hakata port was the origin of the Japanese border control system that Tessa Morris-Suzuki criticized strongly in her book. ${ }^{37}$

All repatriates, including Korean and Japanese, were allowed to carry only 1,000 yen with them under the policy of SCAP. They were able to exchange their money at the port of embarkation at the rate of one Korean won to one Japanese yen. Gold and silver in excess of normal personal property standards, securities, financial instruments, guns, cameras, gems, valuable art objects, and stamp collections could not be exported in principle. The people going on board could carry only essential items including ordinary personal possessions and clothing. A receipt was given to the repatriates for all funds or property taken under custody of the U.S. Army at the port. There was a limit to the baggage weight of up to 150 pounds that a person could carry on board the ship. The most important reason that SCAP forced the policy on currency movement was to curb inflation both in Japan and in Korea. ${ }^{38}$

The Japanese government went on to integrate the relief organizations under the direction of the Welfare Ministry. The demobilized soldiers were under the control of the Veterans Ministry and civil repatriates were under local government control. On November $22^{\text {nd }}$, the Department of Relief for Repatriates (Hikiageengo-ka) in the Social Bureau of the Welfare Ministry was created as the first integrated organization in the central government. However, the Department assumed responsibility only for the relief of Japanese repatriates, while the Well-Being Department (Hukuri-ka) of the Social Bureau was in charge of non-Japanese repatriates. Then on November $24^{\text {th }}$, the Japanese government established the Relief Bureau of Repatriates (Hikiageengo-kyoku) as the local integrated

37 Morris-Suzuki, Borderline Japan, passim.

38 William J. Gane, "Foreign Affairs of South Korea, August 1945 to August 1950" (PhD Diss., Northwestern University, 1951), 157-8. 
organization with seven repatriation posts including Hakata port. ${ }^{39}$ Fukuoka Prefecture took another administrative step, creating the Office for Repatriates in the port on November $15^{\text {th }}$. As a result, the old Office for Repatriates and the newly created Relief Bureau of Repatriates coexisted uncomfortably in the port until the time when relief services were absorbed completely by the latter on February $1^{\text {st }}, 1946 .^{40}$

\section{Conclusion}

This study examines the process of the relief system for repatriates implemented at Hakata port for three months after the war ended. The findings give vivid testimony to the severe ethnic discrimination against Koreans compared to Japanese repatriates at that time. Consequently, this situation started to improve only after the arrival of the occupational forces in Fukuoka prefecture. A remarkable finding of this study is that the GGC played an important role in the first stage of sending back repatriates. An additional finding is that the efforts of the Fukuoka officers were disproportionately directed towards Japanese repatriates rather than Koreans repatriates in the early stages of relief services. As a result, this article reveals the need to have a thorough understanding of the circumstances surrounding the repatriates in Japan with a focus on ethnicity-based discrimination.

However, we cannot conclude that ethnic discrimination against Korean repatriates was completely eliminated, even though it began to subside after the establishment of the Interim Office for Repatriates. For further clarification and understanding regarding the relief activities for repatriates after the second world war, it is necessary to conduct research with additional resources of not only documents issued by the Hakata Repatriation Relief Bureau or the Fukuoka Prefectural Government. Moreover,

39 Hikiage Engochou, Hikiage Engo no Kiroku, 66.

40 Hakata Hikiage Engo Kyoku, Kyokushi, 67. 
it is necessary to closely examine the efforts of the Military Government Team in Fukuoka and the Hakata Liaison of USAMGIK to understand the ethnic discrimination in relief service provisions for repatriates at the port. Finally, much research in still needed on what Korean volunteer groups actually did for the relief of Korean returnees under highly adverse circumstances.

\section{References}

1. Choi, Young Ho. Pugwan Yŏllaksŏn'gwa Pusan (PusanShimonoseki Cross-channel Liner and Pusan). Seoul: Nonhyung Publishing, 2007.

2. Choi, Young Ho. Ilbonin Sehwahoe: Singminji Chosŏn Ilboninŭi Chŏnhu (Japanese Relief Society, Post-colonial Repatriates). Seoul: Nonhyung Publishing, 2013.

3. Darmstadter, Mary Virginia. "The Korean Minority in Post-War Japan: Repatriation of Korean Residents in Japan." MA Diss., The American University, 1963.

4. Gane, William J. "Foreign Affairs of South Korea, August 1945 to August 1950.” PhD Diss., Northwestern University, 1951.

5. Imaizumi, Yūmiko et al. Nihon Teikoku Hōkaiki 'Hikiage' no Hikaku Kenkyu $\bar{u}$ (Comparative Research on the Repatriation in the Time of Collapse of Japanese Empire). Tōkyō: Nihon Keizai Hyōronsha, 2016.

6. Izumi, Kaoru. "Haisengo no Hakatakō ni okeru Chōsenjin Kikoku ni tsuite: Hakata Hikiage Engokyoku 'Kyokushi' wo Chūshin ni site (Korean Repatriates in Hakata Port after the Defeat: Investigation mainly on the History of the Bureau)." Hōsei Kenkyū 60-1 (1993).

7. Lee, Changsoo et al. Koreans in Japan: Ethnic Conflict and Accommodation. Berkeley \& Los Angeles: University of California Press, 1981.

8. Masuda, Hiroshi. Dainippon Teikoku no Hōkai to Hikiage Hukuin (Breakdown of the Japan's Great Empire and Japanese Repatriation). 
Tōkyō: Keiō University Press, 2012.

9. Morris-Suzuki, Tessa. Borderline Japan: Foreigners and Frontier Controls in the Postwar Era. New York: Cambridge University Press, 2010.

10. Park, Kyeong Sik. Kaihōgo Zainichi Chōsenjin Undōshi (History of the Movements of Koreans in Japan after Liberation). Tōkyō: Sanichishobō, 1989.

11. Uchida, Jun. Brokers of Empire: Japanese Settler Colonialism in Korea 1876-1945. Cambridge: Harvard University Asia Center, 2011.

12. Wagner, Edward W. The Korean Minority in Japan: 1904-1950. New York: Institute of Pacific Relations, 1951.

13. Wakatsuki, Yasuo. Sengo Hikiage no Kiroku (Records of the Postwar Repatriation). Tōkyō: Jijitsūsinsha, 1991.

14. Watt, Lori. When Empire Comes Home: Repatriation and Reintegration in Postwar Japan. Cambridge: Harvard University Asia Center, 2009. 


\section{Institutionalizing Japan's Relief System for Repatriates: Koreans and Japanese at Hakata Port in 1945}

This research focuses on the formation process of the relief system for repatriates at Hakata port, located in Fukuoka prefecture during the first three months, after the unconditional surrender by the Japanese Imperial Government on August 14, 1945, until the establishment of the Interim Office for Repatriates in Fukuoka on November 15. It highlights the ethnic discrimination by Japanese officers displayed to Korean returnees. In comparison with Japanese repatriates, Korean returnees faced challenging health conditions with respect to transport, shelter, nutrition, inspection and other basic services. Before the arrival of the local occupation forces in the port, Korean repatriates had to bear systematic discrimination by the Japanese government, the Government General of Chosŏn, and the Fukuoka Prefectural government.

Keywords: Repatriates, Hakata, Fukuoka, Government General of Chosŏn, SCAP, Interim Office for Repatriates 


\section{〈국문초록〉}

\section{일본 귀환원호체계의 제도화 : \\ 1945년 하카타 항구의 조선인과 일본인 귀환자를 중심으로}

최영호 (영산대 일본비즈니스학과 교수)

이 연구는 일본 패전 이후 3 개월 동안, 즉 일본이 포츠담 선언을 수락한 시점에 서부터 11 월 15 일 하카타 항구에 후쿠오카현 임시인양민사무소가 설치될 때까지 후쿠오카현 하카타 항구에서 귀환자를 위한 원호 체계를 어떻게 갖추어 갔는지 역사적 자료를 분석하고 있다. 관련자료를 통하여 일본중앙정부, 조선총독부, 후 쿠오카현 지방정부, 점령당국의 귀환자 원호 문제에 관한 관여 실태를 밝히고 있 다. 이 시기는 아직 한반도 38 도선 이북과 중국 북부의 일본인 민간인 전쟁피해 자들 대부분이 현지에 억류된 상태에서 발이 묶어 있던 시기로 대부분의 일본인 귀환자들이 한반도 38 도선 이남지역의 거주자였다. 따라서 식민지시기에 전쟁협 력을 요청하기 위해 '내선일치'를 외치던 일본정부 관리들의 행태가 한반도로 돌 아오는 조선인들에게 일본에 대한 인식을 성격지우는 시기였다. 이 연구는 후쿠오 카에 점령군이 도착할 때까지 일본의 공식적인 귀환 관련 업무 담당자들이 수송 과 집단수용, 배급, 검역 등 공식적인 서비스에서 일본인 귀환자와 조선인 귀국자 에 대한 차별적인 대우를 실시했다는 점을 밝히고 이것이 해방직후 조선인의 반 일감정을 북돋우게 되는 원인이 되었다고 보고 있다.

주제어: 귀환자, 하카타, 후쿠오카, 조선총독부, 연합국군총사령부, 임시인양민 사무소 